\title{
Vpliv namakanja v kombinaciji s tehnologijo nege ledine na razporeditev, migracijo ter vsebnost nitrata in bakra $v$ tleh oljčnih nasadov
}

\author{
Maja PODGORNIK ${ }^{1}$
}

Received March 06, 2018; accepted Sptember 06, 2018.

Delo je prispelo 06. marca 2018, sprejeto 06. septembra 2018.

\section{IZVLEČEK}

Vse pogostejši in intenzivnejši ekstremni vremenski dogodki (višje temperature - intenzivnost in pogostnost vročinskih valov, več daljših sušnih obdobij) ter vremensko pogojene bolezni in škodljivci, ki so v zadnjih letih povzročili največ škode $\mathrm{v}$ pridelavi oljk, opozarjajo na nujne spremembe $\mathrm{v}$ slovenskem oljkarstvu. Zaradi spoznanja, da imajo prilagoditve kmetijske pridelave na podnebne spremembe lahko negativne posledice na okolje (vodo, tla), smo z zasnovanim poskusom želeli ugotoviti dejanski učinek prilagoditev agrotehničnih ukrepov na dinamiko nitrata in bakra v tleh. Rezultati raziskave so pokazali, da namakanje $\mathrm{v}$ kombinaciji s tehnologijo nege ledine vpliva na razporeditev, migracijo in vsebnost nitrata in bakra $\mathrm{v}$ tleh oljčnih nasadov. Dodana voda lahko ob tem, da omogoča nemoten sprejem hranil $\mathrm{v}$ rastlino, izboljša tudi razmere za mineralizacijo in razgradnjo organske snovi, ki je močno odvisna od načina oskrbe in nege ledine.

Key words: tla; nitrat; baker; oljka; namakanje

\section{ABSTRACT \\ THE EFFECT OF IRRIGATION IN COMBINATION WITH SOIL CULTIVATION ON DISTRIBUTION, MIGRATION AND CONTENT OF NITRATE AND COPPER IN THE SOILS OF OLIVE GROVES}

The more frequent and intense extreme weather events (higher temperatures - the intensity and frequency of heat weaves, more and longer periods of drought) and weather-related diseases and pests, that have caused the greatest damage to olive production in the recent years, are a warning that urgent changes to Slovenian olive culture are needed. Due to the realisation that adaptations of agricultural production to climatic changes can have negative effects on the environment (water, soil), we conducted an experiment to determine the actual effect of adaptations of agro-technical management on the dynamics of nitrate and copper in the soil. The results of the study have shown that irrigation in combination with the technology of soil cultivation have effect on the allocation, migration and content of nitrate and copper in the soil of olive groves. Along with the fact that applied water allows the undisturbed absorption of nutrients into the plant, it can also improve the conditions for mineralisation and decomposition of organic matter, which is heavily dependent on the type of soil cultivation.

Ključne besede: soil; nitrate; copper; olive; irrigation

\section{UVOD}

Slovenija predstavlja skrajno severno mejo, kjer se oljka lahko še goji na obsežnih zemljiščih (Sancin, 1990). Čeprav so za slovensko oljkarstvo značilna majhna kmetijska gospodarstva $(85 \%$ KMG kmetijsko gospodarstvo ima od 0,1 do 1 ha oljčnikov), posebno geografsko območje pridelave oljk omogoča pridelavo visoko kakovostnega oljčnega olja z zaščiteno označbo porekla »EDOOSI ZOP - Ekstra deviška oljčna olja Slovenske Istre« (Strategija za izvajanje resolucije..., 2014).
Vse pogostejši in intenzivnejši ekstremni vremenski dogodki (višje temperature - intenzivnost in pogostnost vročinskih valov, več daljših sušnih obdobij) ter vremensko pogojene bolezni in škodljivci, ki so v zadnjih letih povzročili največ škode v pridelavi oljk, opozarjajo na nujne spremembe $v$ slovenskem oljkarstvu. Številni avtorji že poročajo o vplivih klimatskih sprememb na količino pridelka oljk in kakovost oljčnega olja (Dag in sod., 2014; Ozdemir, 2016). Ponti in sod. (2014) ter Kajfež-Bogataj (2005) opozarjajo, da se bodo stroški pridelave oljk, zaradi

1 dr., Znanstveno-raziskovalno središče Koper, Inštitut za oljkarstvo, Garibaldijeva 1, 6000 Koper, Slovenija, maja.podgornik@zrs-kp.si 
prilagajanja podnebnim spremembam in evropske kmetijske politike, ki vse bolj subvencionira intenzivno pridelavo kot ekološko pridelavo, povečali. To bo najbolj ogrozilo obstoj majhnih oljkarjev, katerih ohranjanje in razvoj imata pomembno vlogo pri poseljenosti podeželja, varovanju biotske pestrosti, kmetijskih tal in značilnosti kmetijske krajine.

Zaradi prilagoditev pridelave oljk na novo nastale razmere in vse večje potrebe po zagotavljanju zadostne količine kakovostnih in konstantnih pridelkov nekateri slovenski oljkarji že uporabljajo princip »kriznega namakanja«, kjer gre za časovno in količinsko nekontrolirano dodajanje vode (Pintar in sod., 2010; Podgornik \& Bandelj, 2015). Nestrokovno namakanje v kombinaciji z neuravnoteženim gnojenjem (prekomernim odmerkom dušika), ki ne upošteva potreb rastline, fizikalnih lastnosti tal, evapotranspiracije ter časovne razporeditve in jakosti padavin, ima lahko negativni vpliv na okolje in vodne vire, saj obstaja nevarnost, da se dodana hranila izperejo v globlje plasti tal, podtalnico ter vodotoke in se tako vključijo $\mathrm{v}$ našo prehranjevalno verigo. Dušik se v obliki nitrata v slini ustne votline izredno hitro pretvori v nitrit $\left(\mathrm{NO}_{2}{ }^{-}\right)$, ki pri motenem izločanju kisline $\mathrm{v}$ želodcu reagira $\mathrm{z}$ amini in tvori močne rakotvorne nitrozamine (Scharpf, 1991). Poleg tega lahko nitrit v krvi reagira s hemoglobinom in povzroči methemoglobinemijo dojenčkov (Consalter in sod., 1992). Zaradi negativnega učinka nitrata na zdravje ljudi je svetovna zdravstvena organizacija (WHO $=$ World Health Organization) postavila mejno vrednost za količino nitrata $\mathrm{v}$ pitni vodi $\left(50 \mathrm{mg} \mathrm{NO}_{3}^{-} \mathrm{kg}^{-}\right.$ 1) (WHO, 1993), znanstveni odbor za živila (SCF = Scientific Committe for Food) pa mejo sprejemljivega dnevnega vnosa nitrata $\mathrm{v}$ človeško telo (do $3,65 \mathrm{mg}$ $\mathrm{NO}_{3}^{-} \mathrm{kg}^{-1}$ telesne teže) (Reports of the scientific committee for food, 1997).

Spremenjene podnebne razmere vse bolj vplivajo tudi na pojav, razvoj in širjenje rastlinskih bolezni (Sutherst in sod., 1995; Chakraborty in sod., 2000). Zaradi milih in vlažnih zim se $\mathrm{v}$ slovenskih oljčnikih $\mathrm{v}$ vse večjem obsegu pojavlja oljkova kozavost ali pavje oko (Cycloconium oleaginum Cast.), ki je najbolj znana in razširjena bolezen oljk na celotnem sredozemskem območju. Sorte oljk so na omenjeno bolezen različno občutljive. Med slovenskimi sortami je zelo občutljiva 'Istrska belica', ki je v slovenskih oljčnikih najbolj zastopana (70 \% - oljčnih dreves). Poleg tega mora biti v sortni sestavi oljk, iz katerih je pridelano oljčno olje z oznako zaščiteno označbo porekla »EDOOSI ZOP Ekstra deviška oljčna olja Slovenske Istre«, najmanj $30 \%$ sorte 'Istrska belica'. Zaradi velikega pomena in zastopanosti sorte 'Istrska belica' v slovenskem prostoru, ugodnejših podnebnih razmer za razvoj rastlinskih bolezni in vse večjega pojava pavjega očesa na območju slovenskih oljčnikov obstaja bojazen prekomerne uporabe in kopičenja bakrovih pripravkov v tleh oljčnih nasadov. V Sloveniji je v skladu s Seznamom registriranih fitofarmacevtskih sredstev (2018) za zaščito oljk pred oljkovo kozavostjo ali pavjim očesom in oljkovo sivo pegavostjo (Mycocentrospora cladosporioides (Sacc.) P. Costa ex Deighton) edino registrirano in učinkovito sredstvo na osnovi bakrovega oksiklorida. Baker je pri majhnih koncentracijah esencialni element, ki je nujno potreben vsem živim organizmom (Gessa in Ciavatta, 2005). Velike koncentracije bakra, ki nastanejo $\mathrm{v}$ tleh zaradi uporabe in kopičenja bakrovih pripravkov za zaščito rastlin, pa toksično vplivajo na makro in mikro floro in favno ter tako na zmanjšano biološko aktivnost tal (Georgopoulos in sod., 2001; Besnard in sod., 2001).

Zaradi spoznanja, da imajo prilagoditve kmetijske pridelave na podnebne spremembe lahko negativne posledice na okolje (vodo, tla), smo z zasnovanim poskusom želeli ugotoviti dejanski učinek prilagoditev agrotehničnih ukrepov na dinamiko nitrata in bakra $\mathrm{v}$ tleh. Glede na to, da je obremenjenost okolja rezultat prepletanja različnih rab tal, smo želeli $\mathrm{z}$ raziskavo ovrednotiti vplive prilagoditve pridelave oljk na onesnaženost okolja in $\mathrm{s}$ tem pridobiti vpogled $\mathrm{V}$ problematiko prilagajanja kmetijske pridelave na podnebne spremembe. Nova spoznanja nam bodo omogočila okoljsko varno zamenjavo starih neučinkovitih agrotehničnih ukrepov in praks z novimi, ki omogočajo boljši neposreden odziv oljk na podnebne spremembe.

\section{MATERIAL IN METODE}

\subsection{Opis poskusnih lokacij}

V letu 2010 smo v oljčniku 'Istrska belica' na lokacijah Strunjan in Dekani zasnovali poskus spremljanja nitrata $\mathrm{v}$ odcedni vodi in tleh ter vsebnost bakra $\mathrm{v}$ tleh. $\mathrm{Na}$ vsaki izbrani lokaciji smo na namakanih in nenamakanih površinah od 1.8.2010 do 16.11.2011 spremljali vsebnost nitrata $\mathrm{v}$ odcedni vodi in tleh in od 19.8.2010 do 21.7.2011 vsebnost bakra v tleh.
V poskusnih oljčnikih smo 31.8.2010 izkopali pedološki profil do matične podlage, opisali morfološke lastnosti tal, opravili kemične in fizikalne analize ter tako določili lastnosti talnih horizontov posameznega pedološkega profila. S kvantitativnim in kvalitativnim ocenjevanjem ter opazovanjem talnih horizontov so bili določeni talni tipi opazovanih lokacij. 
$\mathrm{V}$ času raziskave smo meteorološke podatke spremljali $\mathrm{z}$ avtomatsko meteorološko postajo SIAP+MICROS Olimpo. V Dekanih (Slika 1) (nadmorska višina: 96 m, zemljepisna širina: $45^{\circ} 33,541$ ', zemljepisna dolžina: $13^{\circ} 47,637^{\prime}$ ) je meteorološka postaja nameščena neposredno v poskusnem oljčniku, medtem ko je v Strunjanu (Slika 1) (nadmorska višina: $175 \mathrm{~m}$, zemljepisna širina: $45^{\circ} 30,732$ ', zemljepisna dolžina: $13^{\circ} 37,896^{\prime}$ ) od poskusne lokacije oddaljena $2 \mathrm{~km}$ zračne linije. V letu 2010 so bile količine padavin (Dekani:
$1380 \mathrm{~mm}$, Mala Seva: $1623 \mathrm{~mm}$ ) nad dolgoletnim povprečjem $(973 \mathrm{~mm})$, medtem ko v letu 2011 niso presegle dolgoletnega povprečja, saj so dosegle le $57 \%$ oz. $69 \%$ (Dekani: $557 \mathrm{~mm}$, Mala Seva: $676 \mathrm{~mm}$ ) običajne količine padavin. Povprečne mesečne temperature zraka pa so tako v letu 2010 (Dekani: $14,0^{\circ} \mathrm{C}$, Mala Seva: $14,2^{\circ} \mathrm{C}$ ) kot v 2011 (Dekani: $14,7^{\circ} \mathrm{C}$, Mala Seva: $15,4^{\circ} \mathrm{C}$ ) presegle dolgoletno povprečje $\left(13,7^{\circ} \mathrm{C}\right)$.

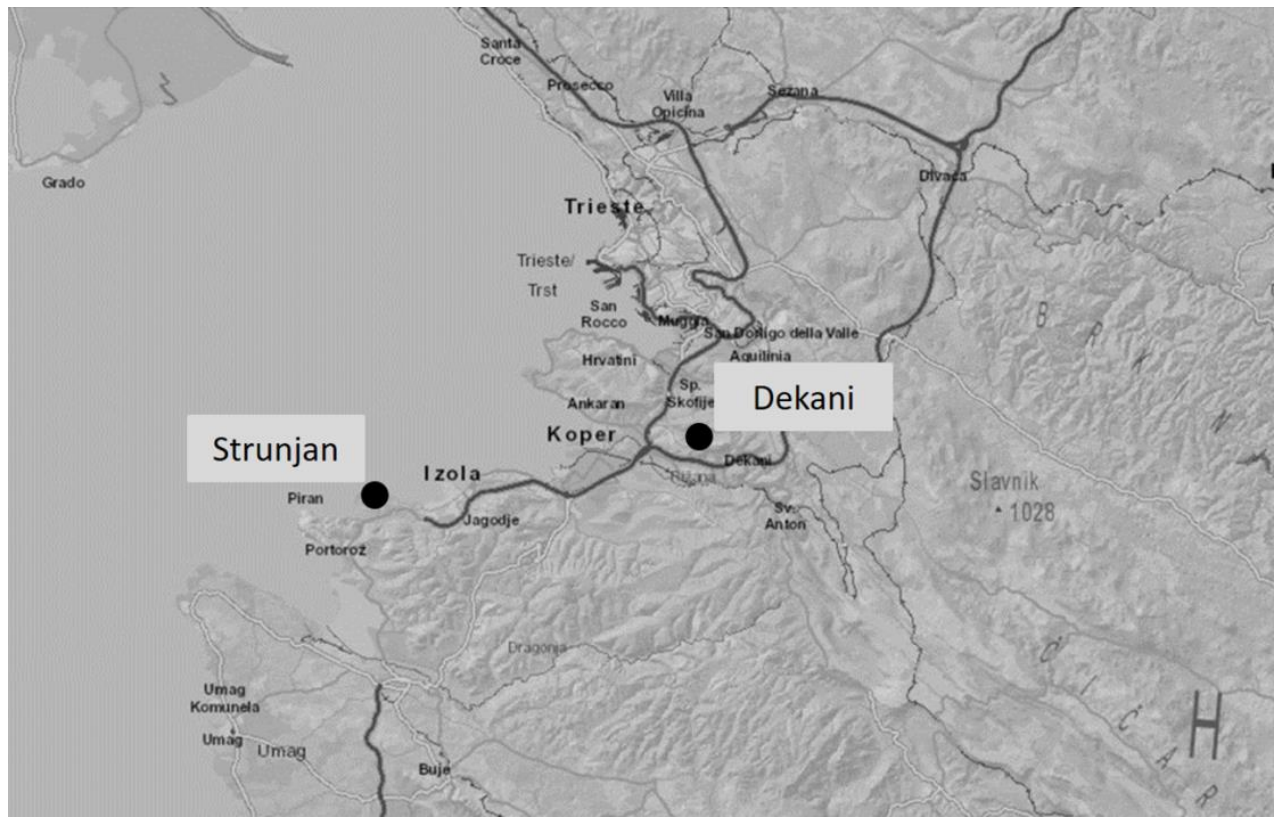

Slika 1: Območje raziskave in lokaciji vzorčenja (Strunjan, Dekani) (Atlas okolja...2018)

Figure 1: Study area and location of sampling (Strunjan, Dekani) (Atlas okolja...2018)

$\mathrm{Z}$ namenom, da bi $\mathrm{v}$ poletnih mesecih nadomestili primanjkljaj vode $\mathrm{v}$ tleh, sta bila leta 2009 na del poskusnih površin nameščena kapljična namakalna sistema. Za zagotavljanje optimalnega namakalnega obroka, ki je bil enak $100 \%$ evapotranspiraciji, sta bila na vsaki izbrani lokaciji vgrajena tenziometra - DL6 Tensimeter Data Logger, ki sta na podlagi zabeleženih polurnih podatkov avtomatsko prožila namakalni sistem. Količine dodane vode na poskusnih lokacijah so predstavljene v Preglednici 1.

Oljčnika sta zatravljena s krajevno prisotno travno rušo. V Dekanih je bila travna ruša košena glede na fenološki stadij rastline, medtem ko je bila travna ruša v Strunjanu mulčena (Preglednici 1).

$\mathrm{V}$ času naše raziskave so $\mathrm{v}$ Dekanih (13.2.2011) in Strunjanu (04.02.2011) v mesecu februarju dodali $37 \mathrm{~kg}$ $\mathrm{N} \mathrm{a}^{-1}$. Tako v Dekanih kot v Strunjanu dodane količine dušika niso dosegle dovoljene mejne vrednosti letnega vnosa dušika $\left(90 \mathrm{~kg} \mathrm{ha}^{-1}\right)$, ki jo Tehnološka navodila za integrirano pridelavo (2011) predpisujejo za oljke.
Za zaščito oljk pred napadom glive Spilocaea oleagina, ki povzroča bolezen pavje oko, je bilo uporabljeno fitofarmacevtsko sredstvo Cuprablau-Z (aktivna snov baker). Količine $\left(\mathrm{kg} \mathrm{ha}^{-1}\right)$ dodane aktivne snovi so navedene v Preglednici 1. 


\section{Maja PODGORNIK}

Preglednica 1: Podatki o agrotehničnih ukrepih v poskusnih oljčnih nasadih

Table 1: Data of agrotechnical work in experimental olive groves

\begin{tabular}{|c|c|c|c|c|c|c|c|c|c|c|c|c|c|}
\hline 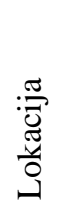 & 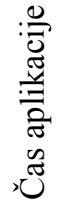 & 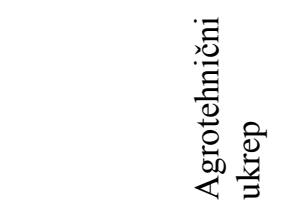 & 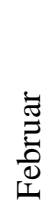 & 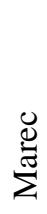 & $\overline{\bar{Q}}$ & $\dot{\Sigma}^{\prime}$ & 寻 & $: \Xi$ & $\begin{array}{l}\vec{w} \\
\overrightarrow{0} \\
\overrightarrow{0} \\
\vec{z}\end{array}$ & 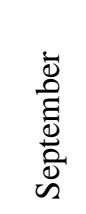 & $\begin{array}{l}\bar{\Delta} \\
\frac{0}{0} \\
\frac{0}{0}\end{array}$ & $\begin{array}{l}\overline{\mathbf{D}} \\
\text { है } \\
0 \\
\text { ठ } \\
z\end{array}$ & 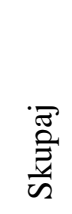 \\
\hline \multirow{7}{*}{$\begin{array}{l}\tilde{\Xi} \\
\frac{\tilde{\pi}}{\Delta} \\
0\end{array}$} & \multirow{3}{*}{$\stackrel{\circ}{\stackrel{1}{\circ}}$} & baker $\left(\mathrm{kg} \mathrm{ha}^{-1}\right)$ & & & & & & & & & & 0,47 & 0,47 \\
\hline & & datum košnje & & & & 15.5 . & & & & 15.9 . & & & 1 \\
\hline & & namakanje (mm) & & & & 11 & 91 & 84 & 33 & 16 & 8 & & 243 \\
\hline & \multirow{4}{*}{$\overline{\widetilde{d}}$} & baker $\left(\mathrm{kg} \mathrm{ha}^{-1}\right)$ & & & 0,47 & & & & & & & 0,47 & 0,94 \\
\hline & & datum košnje & & & & & 1.6. & & & 6.9. & & & / \\
\hline & & gnojenje $\left(\mathrm{kg} \mathrm{N} \mathrm{ha}^{-1}\right)$ & 37 & & & & & & & & & & 37 \\
\hline & & namakanje (mm) & & & & 50 & 57 & 85 & 164 & 70 & 150 & & 576 \\
\hline \multirow{7}{*}{ 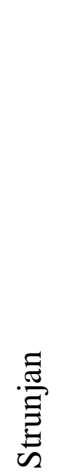 } & \multirow{3}{*}{$\stackrel{\circ}{\stackrel{\circ}{\circ}}$} & baker $\left(\mathrm{kg} \mathrm{ha}^{-1}\right)$ & & & & & & & & & & 1,4 & 1,4 \\
\hline & & datum mulčenja & & & & & & 27.7. & & 09.9 . & & & / \\
\hline & & namakanje (mm) & \multicolumn{11}{|c|}{ Dne 30.7.2010 je prišlo do okvare DL6 Tensimeter Data Logger-ja, zato podatki o porabi vode niso znani } \\
\hline & \multirow{4}{*}{$\overline{\vec{N}}$} & baker $\left(\mathrm{kg} \mathrm{ha}^{-1}\right)$ & & & 1,40 & & & & & & & 1,40 & 2,8 \\
\hline & & datum mulčenja & & & & 3.5. & & & & 30.9 . & & & / \\
\hline & & gnojenje $\left(\mathrm{kg} \mathrm{N} \mathrm{ha}^{-1}\right)$ & 37 & & & & & & & & & & 36 \\
\hline & & namakanje (mm) & \multicolumn{11}{|c|}{ Dne 30. 7. 2010 je prišlo do okvare DL6 Tensimeter Data Logger-ja, zato podatki o porabi vode niso znani. } \\
\hline
\end{tabular}




\subsection{Vzorčenje in analiza vsebnosti nitrata $v$ talni vodi in tleh}

Za spremljanje vsebnosti nitrata $\mathrm{v}$ talni vodi, ki je $\mathrm{v}$ tleh vezna s silo, manjšo od 0,33 bara, in $s$ tem podvržena gravitacijskemu odtoku, smo izbrali keramične vakuumske svečke Pore water sampler - UMS GmbH, model SIC 20. Na vsakem izbranem vzorčnem mestu (1. vzorčno mesto - nenamakano Strunjan; 2. vzorčno mesto - namakano Strunjan; 3. vzorčno mesto nenamakano Dekani; 4. vzorčno mesto - namakano Dekani) smo vkopali 6 keramičnih svečk, s pomočjo katerih smo 1-krat tedensko odvzeli vzorce perkolata oziroma odcedne vode na globini tal $40 \mathrm{~cm}$. Vzorec perkolata je predstavljal povprečni vzorec 6 podvzorcev, pridobljenih iz 6 keramičnih svečk.

Ob vkopanih keramičnih svečkah smo 2-krat mesečno odvzeli tudi povprečne vzorce tal. Vzorčenje smo opravili v zgornjem talnem sloju do globine $50 \mathrm{~cm}$. Vzorec tal $(0,5 \mathrm{~kg})$ je predstavljal povprečni vzorec, pridobljen iz 10 enakomerno razporejenih podvzorcev znotraj posameznega vzorčnega mesta.

Odvzete vzorce vode in tal smo takoj po vzorčenju shranili v zamrzovalno skrinjo $\left(-16{ }^{\circ} \mathrm{C}\right)$. Na odvzetih vzorcih so bile opravljene analize za vsebnost nitratov.
$\mathrm{V}$ vzorcih vode je bil nitrat določen direktno, medtem ko je bil nitrat $\mathrm{v}$ tleh določen $\mathrm{v}$ talnem ekstraktu. Za ekstrakcijo je bil uporabljen $0,01 \mathrm{~mol} \mathrm{l}^{-1} \mathrm{CaCl}_{2}$. Vsebnosti nitrata $\mathrm{v}$ talni vodi in tleh so bile določene spektrofotometrično z aparatom Perkin Elmer UV/VIS Spectrometer Lambada 2, s FIAS sistemom vzorčenja. Analize nitrata v vodi so potekale po standardni metodi SIST ISO 14255 v laboratoriju Centra za pedologijo in varstvo okolja na Biotehniški fakulteti Univerze v Ljubljani.

\subsection{Vzorčenje in analiza vsebnosti bakra $v$ tleh}

Ob vkopanih keramičnih svečkah smo poleg vzorcev za vsebnosti nitrata $v$ tleh 1-krat mesečno odvzeli vzorce tal, v katerih smo ugotavljali vsebnost bakra. Vzorčenje smo opravili v zgornji talni plasti do globine $40 \mathrm{~cm}$. Vzorec tal $(3 \mathrm{~kg})$ je predstavljal povprečni vzorec, pridobljen iz 25 enakomerno razporejenih podvzorcev znotraj posameznega vzorčnega mesta.

$\mathrm{Na}$ odvzetih vzorcih tal so bile takoj po vzorčenju izvedene analize bakra. Analize bakra so bile narejene po standardni metodi SIST ISO 17294, modif: $2003 \mathrm{v}$ laboratoriju Inštituta za varstvo okolja Zavoda za zdravstveno varstvo Maribor.

\section{REZULTATI IN DISKUSIJA}

\subsection{Lastnosti tal}

Na podlagi rezultatov standardne pedološke analize smo tla v Dekanih uvrstili v globoka glineno-ilovnata tla, medtem ko se tla v Strunjanu uvrščajo v meljastoglinena tla (Preglednica 2). Zgornji horizont poskusnih tal v Dekanih je zelo močno humozen $(18,0 \%)$, medtem ko so spodnji horizonti humozni do slabo humozni $(3,1 \%-1,6 \%)$. Humozna do slabo humozna tla so tudi tla v Strunjanu $(3,3 \%-1,4 \%)$. Reakcija tal se na obeh poskusnih lokacijah giblje v območju med $\mathrm{pH} 7,0$ in 7,6, kar predstavlja optimalno okolje za mikrobiološke procese in ugodno vpliva na rast in razvoj oljk. Kationska izmenjalna kapaciteta se $\mathrm{v}$ poskusnih tleh giblje med (35 - 40 mmolc $\left.100 \mathrm{~g}^{-1}\right)$, kar je značilno za

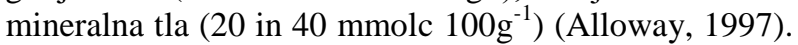
Po Kutileku in Nilsenu (1994) se tla v Strunjanu uvrščajo v tla z zelo slabo propustnostjo za vodo, saj se vrednosti koeficienta hidravlične prevodnosti gibljejo med $0,27-0,85 \mathrm{~cm} \mathrm{dan}^{-1}$, medtem ko se tla v Dekanih uvrščajo v slabo do srednje propustna tla za vodo $(4,04$ $\left.-25,7 \mathrm{~cm} \mathrm{dan}^{-1}\right)$. 


\section{Maja PODGORNIK}

Preglednica 2: Lastnosti tal poskusnih oljčnih nasadov

Table 2: Soil characteristics for the experimental olive groves

\begin{tabular}{|c|c|c|c|c|c|c|c|c|c|c|}
\hline 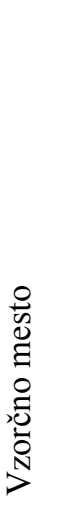 & 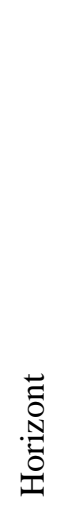 & 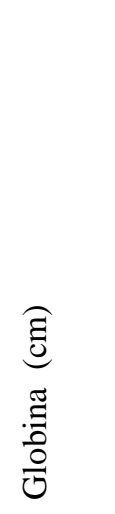 & 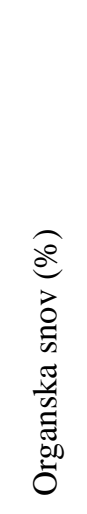 & 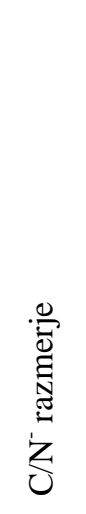 & 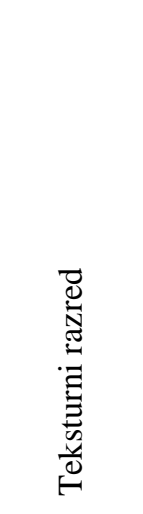 & 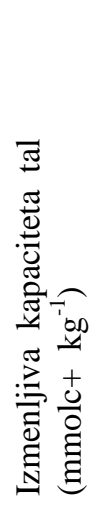 & 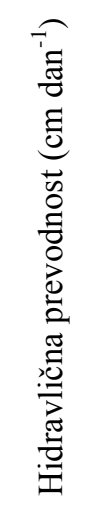 & 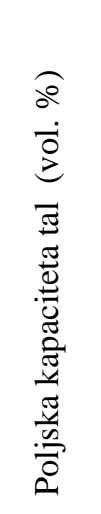 & 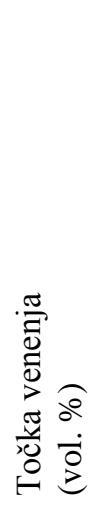 & $\frac{T}{2}$ \\
\hline \multirow{4}{*}{ 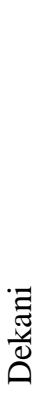 } & $\mathrm{Ah}$ & $0-2$ & 18,0 & 14,4 & I & 40,8 & I & \multirow{4}{*}{32,33} & \multirow{4}{*}{18,56} & 7,0 \\
\hline & $\mathrm{P} 1$ & $2-24$ & 3,1 & 15,0 & GI & 38,8 & 17,48 & & & 7,4 \\
\hline & $\mathrm{P} 2$ & $24-51$ & 2,2 & 10,0 & GI-I & 39,2 & 25,07 & & & 7,4 \\
\hline & P3 & $51-74$ & 1,6 & 11,3 & GI & 37,8 & 4,04 & & & 7,6 \\
\hline \multirow{3}{*}{ 蔦 } & A1 & $0-8$ & 3,3 & 10,0 & MI-MGI & 35,5 & I & \multirow{3}{*}{35,09} & \multirow{3}{*}{24,25} & 7,3 \\
\hline & $\mathrm{P} 1$ & $8-32$ & 1,9 & 8,5 & MI-MGI & 36,9 & 0,27 & & & 7,4 \\
\hline & $\mathrm{P} 2$ & $32-73$ & 1,4 & 7,3 & MI-MGI & 38,2 & 0,85 & & & 7,5 \\
\hline
\end{tabular}




\subsection{Dinamika nitrata v odcedni vodi}

$\mathrm{V}$ večini odvzetih vzorcev tako $\mathrm{v}$ Dekanih kot $\mathrm{v}$ Strunjan so bile vsebnosti nitrata pod mejo detekcije. Največje izmerjene vsebnosti nitrata v vzorcih odcedne vode v Dekanih (nenamakano: 30. 3. $2011-28 \mathrm{mg}$ $\mathrm{NO}_{3}^{-} \mathrm{l}^{-1}$; namakano: 13. 4. $\left.2011-26 \mathrm{mg} \mathrm{NO}_{3}^{-} \mathrm{l}^{-1}\right)$ in Strunjanu (nenamakano: 16. 3. $2011-14 \mathrm{mg} \mathrm{NO}_{3}^{-} \mathrm{l}^{-1}$; namakano:16. 3. $2011-3,5 \mathrm{mg} \mathrm{NO} \mathrm{NO}^{-1}$ ) so bile izmerjene po gnojenju $\mathrm{v}$ času padavin, ki pa niso presegle mejne vrednosti $\left(50 \mathrm{mg} \mathrm{NO}_{3}^{-} \mathrm{l}^{-1}\right)$ za dobro kemijsko stanje podzemnih voda, ki ga predpisuje Uredba o standardnih kakovosti podzemne vode (Uradni list RS, št.100/2005).

$\mathrm{Z}$ analizo odcedne vode smo ugotovili, da so povprečne vsebnosti nitrata v vzorcih nenamakanih $\left(5,36 \mathrm{mg} \mathrm{NO}_{3}{ }^{-}\right.$ $\left.\mathrm{l}^{-1}\right)$ in namakanih površin $\left(2,60 \mathrm{mg} \mathrm{NO}_{3}^{-} \mathrm{l}^{-1}\right)$ v Dekanih, ki so bili odvzeti od 1. 7. 2010 do 16. 11. 2011, večje v primerjavi $\mathrm{z}$ vsebnostmi nitrata $\mathrm{v}$ perkolatu nenamakanih $\left(1,14 \mathrm{mg} \mathrm{NO}_{3}^{-} \mathrm{l}^{-1}\right)$ in namakanih $(0,55 \mathrm{mg}$ $\mathrm{NO}_{3}^{-} 1^{-1}$ ) površin v Strunjanu (Slika 2 in Slika 3). V Dekanih se zaradi pogoste košnje in neodstranjene travne ruše kopičijo velike količine odmrlih rastlinskih ostankov, ki predstavljajo velike zaloge organske snovi v tleh. V zgornjemu horizontu tal v Dekanih smo tako izmerili $18 \%$ organske snovi, medtem ko so bile izmerjene vrednosti organske snovi v zgornjem sloju tal v Strunjanu znatno manjše $(3,3 \%)$. Čeprav imajo tla v
Dekanih boljšo propustnost za vodo kot tla v Strunjanu in bi zato pričakovali večji »razredčitveni efekt«, se je v Dekanih v primerjavi z Strunjanom koncentracija nitrata v odcedni vodi večkrat povečala (september 2010, januar, junij, julij in september 2011) neodvisno od dodane količine gnojila. Glede na navedene rezultate in dejstva predvidevamo, da so bili v Dekanih izpolnjeni vsi pogoji (optimalna temperatura, $\mathrm{pH}$, vlažnost in prezračenost tal) za proces mineralizacije organske snovi $\mathrm{v}$ tleh, ki se je razkrojila (mineralizirala) do osnovnih rastlinskih hranil - nitrata. Nastale količine nitrata so bile večje od potreb rastlin in so se tako izprale $\mathrm{v}$ globlje plasti tal.

Večja nihanja $\mathrm{v}$ vsebnosti nitrata smo zabeležili $\mathrm{v}$ perkolatu namakanih površin izven gnojilnega obdobja, iz česar lahko sklepamo, da je namakanje pomembno vplivalo na proces mineralizacije in razgradnjo organske snovi v tleh. Le to so potrdili tudi Valé in sod. (2007), ki poročajo o vplivu namakanja na mineralizacijo dušika $\mathrm{v}$ toplih klimatskih razmerah. Hkrati je potrebno poudariti, da dodana voda na namakanih površinah omogoča nemoten sprejem hranil $\mathrm{v}$ rastlino in lahko zaradi velikega pretoka vode redči nitrat $\mathrm{v}$ perkolirani vodi, medtem ko pa je voda $\mathrm{v}$ nenamakanih tleh $\mathrm{v}$ času suše vezana $z$ večjo silo, kot jo zmorejo rastline, in se zato hranila ne porabijo, ampak se kopičijo $\mathrm{v}$ tleh in se ob povečanih padavinah izperejo $\mathrm{v}$ globlje plasti tal.

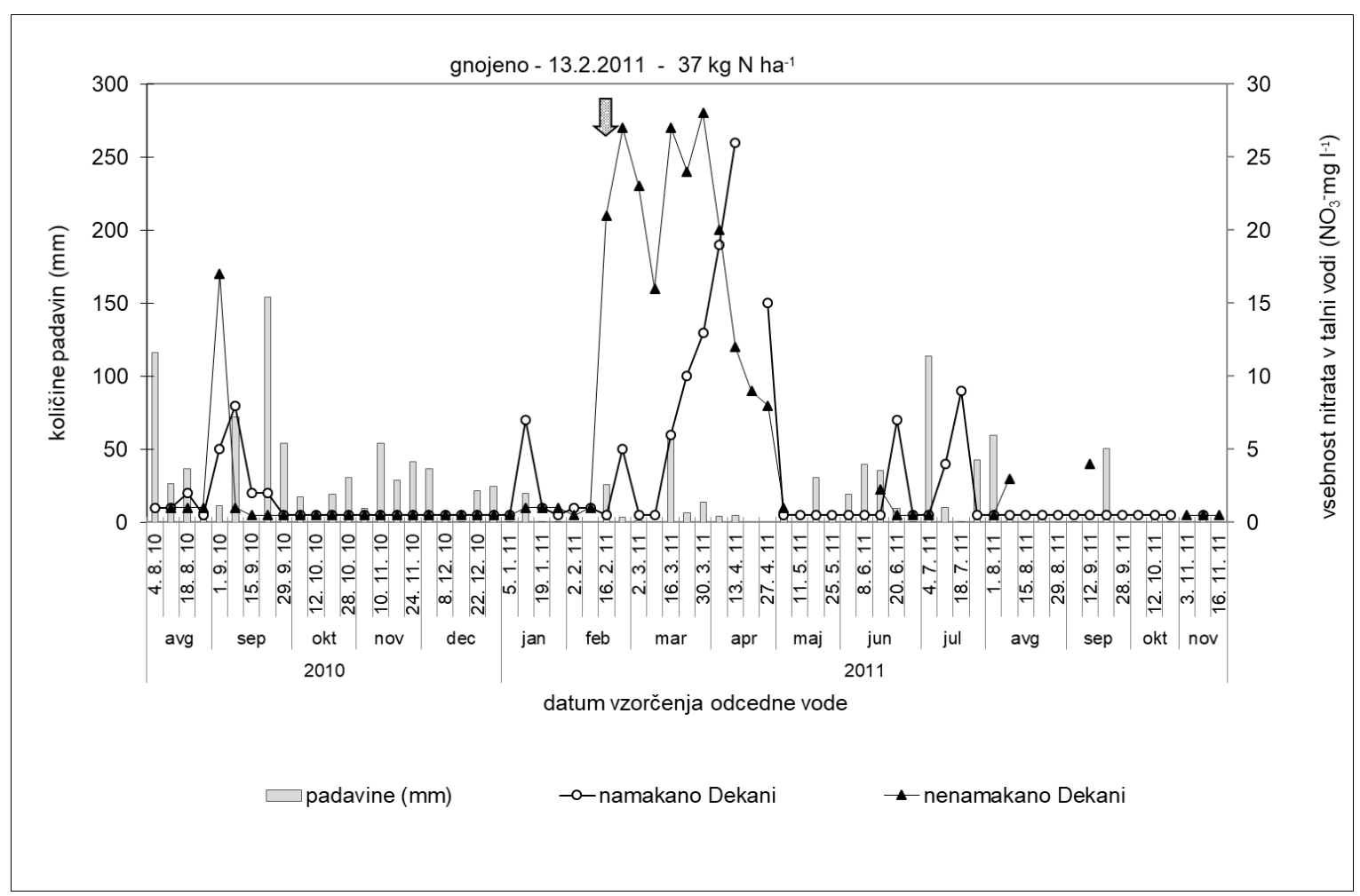

Slika 2: Padavine $(\mathrm{mm})$ in povprečna koncentracija nitrata $\left(\mathrm{NO}_{3}{ }^{-} \mathrm{mg} \mathrm{l}^{-1}\right) \mathrm{v}$ odcedni vodi v Dekanih

Figure 2: Precipitation $(\mathrm{mm})$ and average nitrate concentration $\left(\mathrm{NO}_{3}{ }^{-} \mathrm{mg} \mathrm{l}^{-1}\right)$ in soil water samples for Dekani 


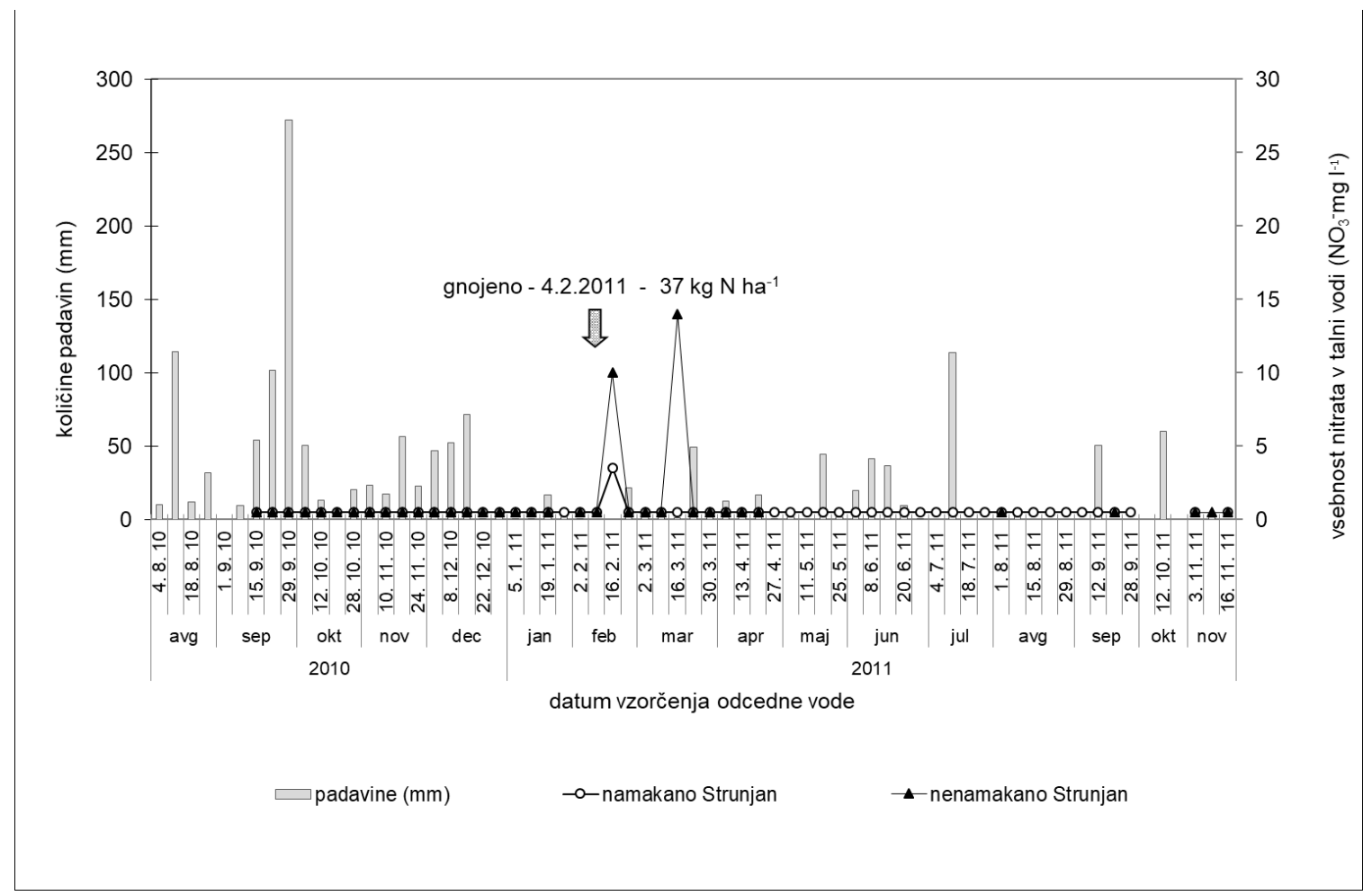

Slika 3: Padavine (mm) in povprečna koncentracija nitrata $\left(\mathrm{NO}_{3}{ }^{-} \mathrm{mg} 1^{-1}\right)$ v odcedni vodi v Strunjanu

Figure 3: Precipitation $(\mathrm{mm})$ and average nitrate concentration $\left(\mathrm{NO}_{3}^{-} \mathrm{mg} \mathrm{l}^{-1}\right)$ in soil water samples for Strunjan

\subsection{Dinamika nitrata $v$ tleh}

Rezultati analize nitrata $\mathrm{v}$ tleh so pokazali, da so povprečne vsebnosti nitrata $\mathrm{v}$ času vegetacijske sezone $\mathrm{v}$ namakanih tleh višje (Dekani: $0,94 \mathrm{mg} \mathrm{NO}_{3}^{-} 100 \mathrm{~g}^{-1}$; Strunjan: 0,51 $\mathrm{mg} \mathrm{NO}_{3}^{-} 100 \mathrm{~g}^{-1}$ ) kot $\mathrm{v}$ nenamakanih tleh (Dekani: 0,24 mg NO${ }_{3}^{-} 100 \mathrm{~g}^{-1}$; Strunjan: $0,32 \mathrm{mg} \mathrm{NO}_{3}{ }^{-}$ $\left.100 \mathrm{~g}^{-1}\right)$. Iz navedenih rezultatov in rezultatov analiz nitrata $\mathrm{v}$ odcedni vodi sklepamo, da namakanje pomembno vpliva na dostopnost nitrata v tleh. Pri tem je potrebno poudariti, da poleg namakanja, dejavnikov okolja in gnojenja na dostopnost dušika $\mathrm{v}$ tleh vpliva tudi način nege ledine oziroma obdelave tal. Iz slik 4 in 5 je razvidno, da se je tako $\mathrm{v}$ tleh, obdelanih $\mathrm{z}$ mulčenjem (Strunjan), kot $\mathrm{v}$ tleh $\mathrm{s}$ trajno ozelenitvijo (Dekani) vsebnost nitrata povečala po ukrepu nege ledine oz. obdelave tal. Gómez in sod. (2009) poročajo, da je trajna ozelenitev tal $\mathrm{v}$ oljčnih nasadih najprimernejši ukrep za varstvo tal in trajnostni način oskrbe tal. Izsledki španske raziskave so potrdili, da rastlinski pokrov zmanjša erozijo tal, zelena masa, ki jo po košnji travne ruše pustimo na tleh, pa povečuje vsebnost organske snovi in tako pozitivno vpliva na fizikalne, kemijske in biološke lastnosti tal (Moreno in sod., 2009). Hkrati pa Gucci in sod. (2012) poročajo, da je $v$ intenzivnih oljčnih nasadih travna ruša konkurenca oljki za vodo in lahko $\mathrm{v}$ sušnih letih povzroči zmanjšanje pridelka. Vsekakor so za ovrednotenje vpliva načina nege ledine na rast in razvoj oljke ter rodovitnost tal potrebne nadaljnje raziskave, s katerimi bo določen optimalni način obdelave tal oljčnih nasadov $\mathrm{v}$ slovenskih klimatskih in talnih razmerah. 
Vpliv namakanja v kombinaciji s tehnologijo ... ter vsebnost nitrata in bakra v tleh oljčnih nasadov

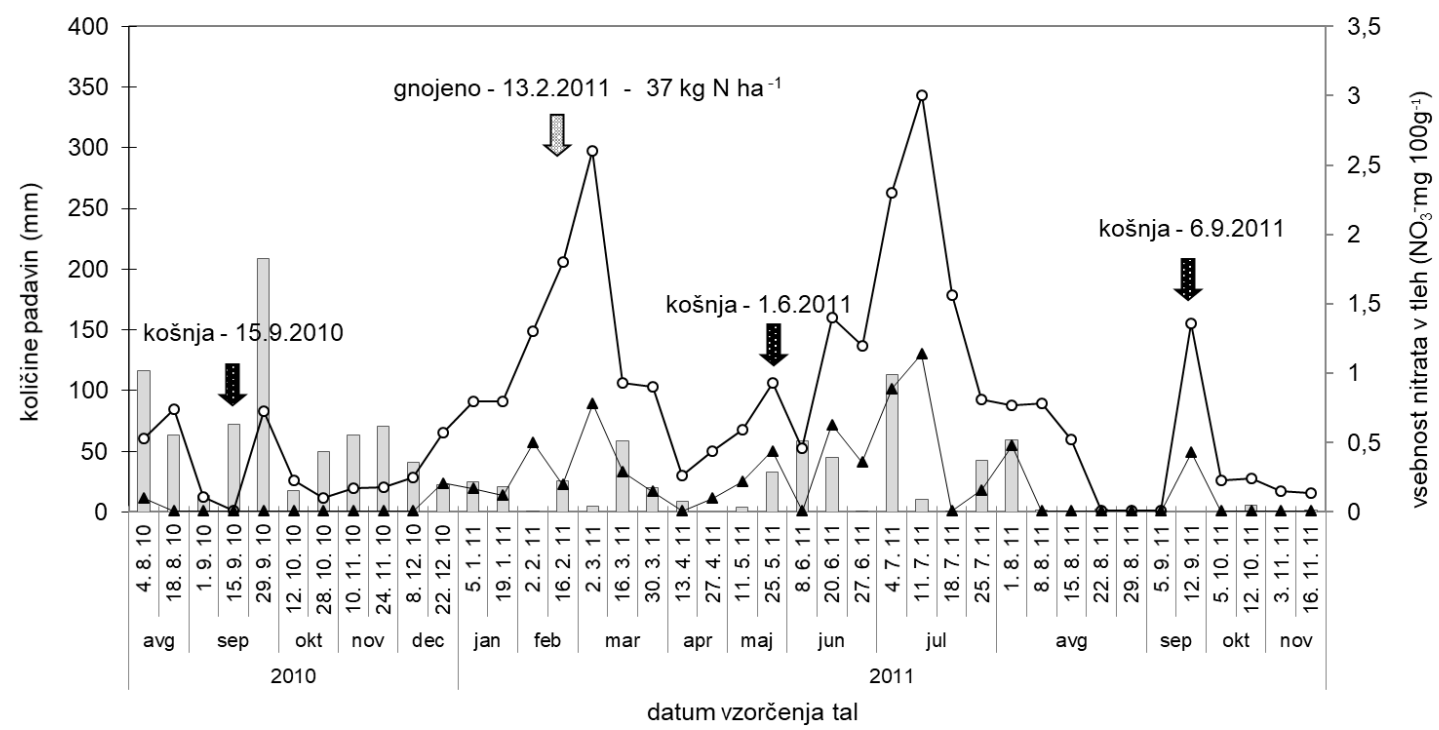

$\square$ padavine $(\mathrm{mm}) \quad \longrightarrow$-namakano - Dekani $\quad \neg$ nenamakano - Dekani

Slika 4: Padavine (mm) in povprečna koncentracija nitrata $\left(\mathrm{NO}_{3}{ }^{-} \mathrm{mg} 100 \mathrm{~g}^{-1}\right) \mathrm{v}$ tleh v Dekanih

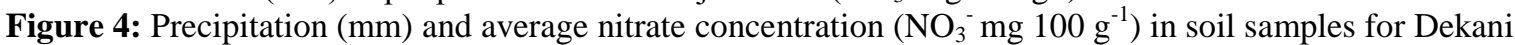

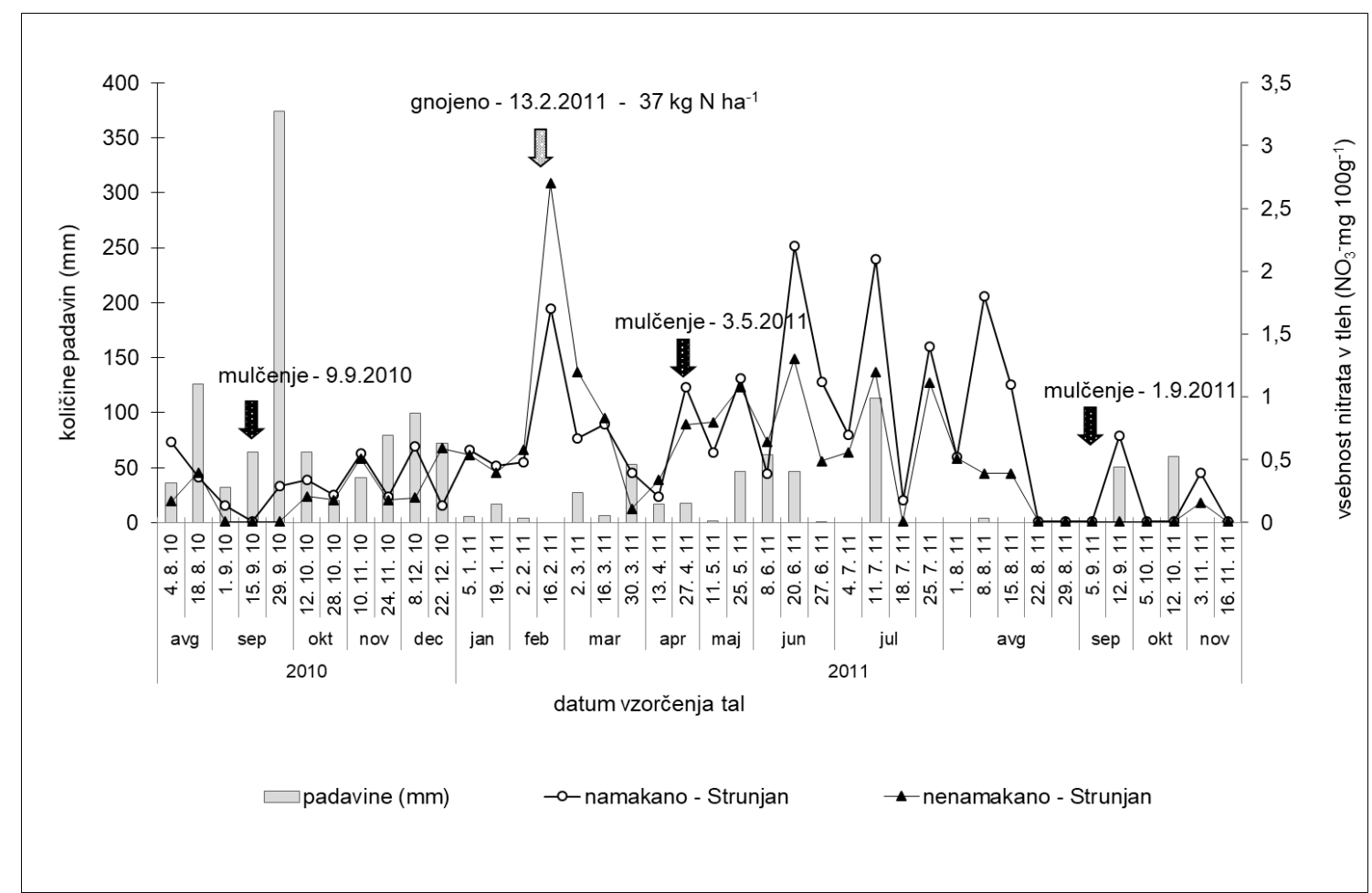

Slika 5: Padavine (mm) in povprečna koncentracija nitrata $\left(\mathrm{NO}_{3}{ }^{-} \mathrm{mg} 100 \mathrm{~g}^{-1}\right) \mathrm{v}$ tleh v Strunjanu

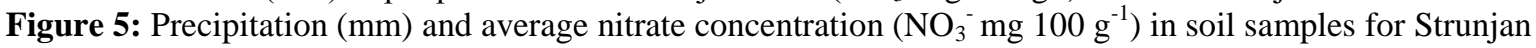




\subsection{Dinamika bakra v tleh}

V preučevanih tleh smo v Strunjanu tako v namakanih kot nenamakanih tleh zabeležili večje koncentracije bakra kot v namakanih in nenamakanih tleh na Dekanih (Slika 6). Koncentracije bakra v vzorcih, odvzetih v Dekanih, so bile od 24 do $39 \mathrm{mg} \mathrm{kg}^{-1}$ suhih tal. V vzorcih, odvzetih v Strunjanu, pa so bile vsebnosti bakra občutno večje $\left(42-68 \mathrm{mg} \mathrm{kg} \mathrm{kg}^{-1}\right.$ suhih tal $)$. Predpostavljamo, da so v Strunjanu večje vsebnosti bakra posledica dolgoletne kmetijske prakse varstva rastlin $\mathrm{z}$ bakrenimi pripravki in večjega deleža bakra, dodanega pri izvedbi fitosanitarnih ukrepov. Pri tem pa je potrebno poudariti, da količina dodanega čistega bakra v Strunjanu $\left(1,40 \mathrm{~kg} \mathrm{ha}^{-1}\right)$ ni presegla zgornje meje skupnega letnega vnosa čistega bakra $\left(6 \mathrm{~kg} \mathrm{ha}^{-1}\right)$, ki jo določa Uredba komisije ES 889/2008 v Prilogi II.

Največje vsebnosti bakra (21.7.2010 - $68 \mathrm{mg} \mathrm{kg}^{-1}$; 27.10.2010 - $67 \mathrm{mg} \mathrm{kg}^{-1} ; 21.4 .2011-68 \mathrm{mg} \mathrm{kg}^{-1}$ ) so bile izmerjene $\mathrm{v}$ namakanih tleh $\mathrm{v}$ Strunjanu in so presegle mejno vrednost za koncentracijo težkih kovin v tleh (60 mg kg-1) (Uradni list RS. št. 62/08). Na območju vinogradov $\mathrm{v}$ submediteranskem delu Slovenije so že leta 2007 vsebnosti bakra v tleh (71 do $160 \mathrm{mg} \mathrm{kg}^{-1}$ ) presegle opozorilne vrednosti (100 $\mathrm{mg} \mathrm{kg}^{-}$ ${ }^{1}$ ) (Rusjan in sod., 2007), ki so bile določene z Uredbo o mejnih vrednostih vnosa nevarnih snovi in gnojil $v$ tla (Uradni list RS, št. 19/17). Precej večje vrednosti so bile zabeležene na vinogradniških območjih Francije (Bordeaux $800 \mathrm{mg} \mathrm{kg}^{-1}$ ) (Delas, 1963), kjer so več kot sto let za varstvo rastlin uporabljali bakrene pripravke. Res je, da je baker za rastline esencialni mikroelement in kot tak nujno potreben za rast in razvoj rastlin, vendar velike vsebnosti bakra povzročajo fitotoksičnost, kar se kaže v zmanjšani sposobnosti preživetja, zmanjšani rasti korenin, zaostanku $\mathrm{v}$ cvetenju, klorozi listov in zmanjšani tvorbi plodov ter manjši količini semen (Brun in sod., 2003; Alloway in Shorrocks, 1988).

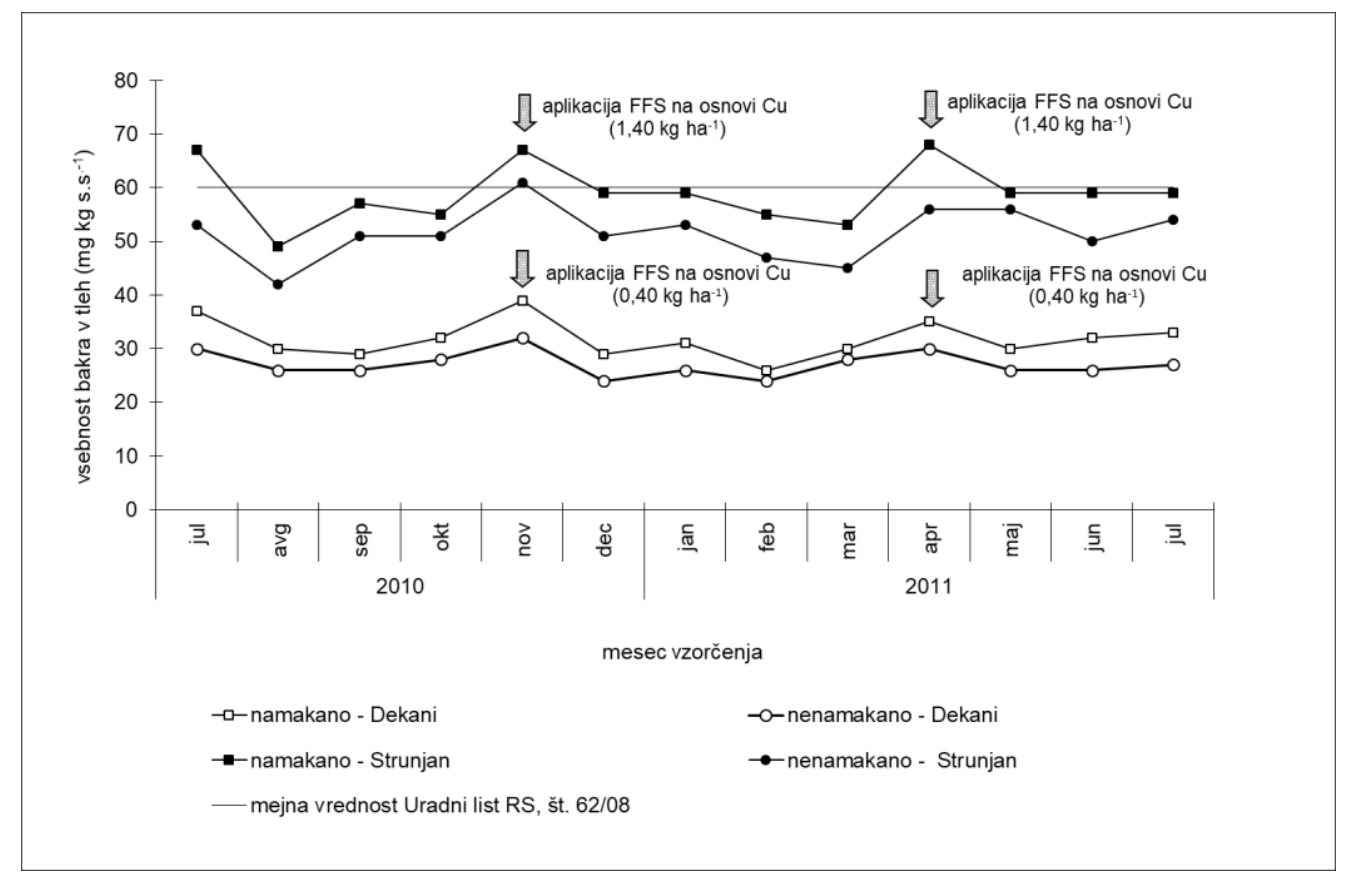

Slika 6: Vsebnost bakra $\left(\mathrm{mg} \mathrm{kg}^{-1}\right)$ v vzorcih tal v Strunjanu in Dekanih.

Figure 6: Content of copper $\left(\mathrm{mg} \mathrm{kg}^{-1}\right)$ in soil samples for location Strunjan and Dekani.

Velik vpliv na vsebnost bakra v tleh ima tudi namakanje tal (Slika 6). Rezultati raziskave so pokazali, da je povprečna vsebnost bakra $\mathrm{v}$ namakanih tleh tako $\mathrm{V}$ Dekanih ${ }^{1}$ (32 $\left.\mathrm{mg} \mathrm{kg}^{-1}\right)$ kot v Strunjanu (59 $\mathrm{mg} \mathrm{kg}^{-1}$ ) večja $\mathrm{v}$ primerjavi $\mathrm{s}$ povprečno vsebnostjo bakra $\mathrm{v}$ nenamakanih tleh (Dekani - $27 \mathrm{mg} \mathrm{kg}^{-1}$; Strunjan - 51 $\mathrm{mg} \mathrm{kg}^{-1}$ ). Baker se $\mathrm{v}$ bazičnih karbonatnih tleh (tla nastala na flišu), kamor uvrščamo tudi poskusna tla $\mathrm{v}$ Dekanih in Strunjanu (slabo alkalna pH 7,0 - 7,6), zelo hitro in trdno veže na negativno površino talnih delcev - koloidov v obstojno obliko, kar močno vpliva na delež topnega in rastlinam dostopnega bakra $\mathrm{v}$ talni raztopini (Alloway in Shorrocks, 1988).

V vlažnih razmerah (padavine, namakanje) se ob nadaljnjem preperevanju bazični minerali izpirajo $\mathrm{v}$ nižje plasti tal. Posledica takih procesov je prehajanje vezanih bazičnih ionov $\mathrm{v}$ talno raztopino, njihova mesta pa zasedejo vodikovi ioni $\left(\mathrm{H}^{+}\right)$. Zaradi nadaljnjega izpiranja bazičnih ionov v nižje plasti tla niso več $100 \%$ 
zasedena $\mathrm{z}$ bazami in zato lahko absorbirani vodikovi ioni na površini talnih koloidov prehajajo $\mathrm{v}$ talno raztopino in znižujejo $\mathrm{pH}$ tal. Zaradi velike koncentracije vodikovih ionov $\mathrm{H}^{+} \mathrm{v}$ talni raztopini ti močno konkurirajo in izpodrivajo kovinske katione (bakra) iz vezanih mest na talnih koloidih. Posledično se $\mathrm{z}$ zniževanjem $\mathrm{pH}$ vrednosti talne raztopine veča delež bakra $\mathrm{v}$ talni raztopini in dostopnost bakra sami rastlini (Vitanović, 2012). Ti procesi so lahko vzrok, da je delež bakra $\mathrm{v}$ namakanih tleh nekoliko večji $\mathrm{v}$ primerjavi $\mathrm{z}$ vsebnostjo bakra $\mathrm{v}$ nenamakanih tleh. Iz zgoraj navedenega gre zaključiti, da so potrebne nadaljnje raziskave vsebnosti bakra $\mathrm{v}$ namakanih tleh, $\mathrm{s}$ katerimi bo natančneje ovrednoten vpliv dodane vode na kroženje bakra $\mathrm{v}$ tleh. Zaključimo lahko, da je poleg lastnosti tal $(\mathrm{pH}$ tal, kationske izmenjevalne kapacitete, železovih in manganovih kationov, vsebnosti organske snovi ...) tudi vsebnost vode $\mathrm{v}$ tleh eden izmed pomembnejših dejavnikov, ki vpliva na vsebnost bakra $\mathrm{v}$ tleh.

\section{SKLEPI}

Rezultati raziskave so pokazali, da namakanje $\mathrm{v}$ kombinaciji s tehnologijo nege ledine vpliva na razporeditev, migracijo in vsebnost nitrata in bakra $\mathrm{v}$ tleh. Poleg tega, da dodana voda omogoča nemoten sprejem hranil v rastlino, lahko izboljša tudi razmere za mineralizacijo in razgradnjo organske snovi, ki je močno odvisna od načina oskrbe in nege ledine. $\mathrm{S}$ trajno ozelenitvijo in puščanjem rastlinskih ostankov na površini tal lahko povečamo zaloge organske snovi $\mathrm{v}$ tleh, kar $\mathrm{v}$ kombinaciji $\mathrm{z}$ optimalnimi okoljskimi razmerami vpliva na vsebnost nitrata. $\mathrm{Za}$ boljše razumevanje in ovrednotenje vpliva načina nege ledine na rast in razvoj oljke ter fizikalne, kemijske ter biološke lastnosti tal so potrebne nadaljnje raziskave, $\mathrm{s}$ katerimi bo določen optimalni način obdelave tal oljčnih nasadov v slovenskih klimatskih in talnih razmerah.

Ugotovljeno je bilo tudi, da je pri načrtovanju in uvajanju prilagoditvenih ukrepov na klimatske spremembe $\mathrm{v}$ kmetijski pridelavi potrebno upoštevati interakcijo med ukrepi ter vpliv le-teh na druge ranljive sisteme. Kljub temu, da je bila raziskava časovno in prostorsko omejena, nam bodo nova spoznanja omogočila okoljsko varno zamenjavo starih neučinkovitih agrotehničnih ukrepov in praks z novimi ter morda odkrila nove možnosti prilagoditev na podnebne spremembe. Za zagotavljanje varovanja okolja pri izvajanju prilagoditvenih ukrepov bi bilo potrebno preučiti tudi učinek prilagoditev agrotehničnih ukrepov na velikost in kakovost pridelka ter ekonomsko vzdržnost pridelave.

V slovenskih oljčnikih bi bilo potrebno, zaradi vse pogostejših in večjih napadov škodljivcev in bolezni, ki zahtevajo večkratno zaporedno tretiranje $\mathrm{z}$ bakrenimi pripravki ter blaženja posledic suše $\mathrm{z}$ namakanjem, ki močno vplivajo na dinamiko bakra $v$ tleh, opraviti tudi inventarizacijo bakra $\mathrm{v}$ tleh. Le tako bi lahko preventivno preprečili degradacijske procese tal, ki so $\mathrm{v}$ svetu prepoznani kot ena največjih groženj okolju z direktnim vplivom na blagostanje prebivalstva.

\section{VIRI}

Alloway, B.J. (1997). Chemical principles of environmental pollution. London, Blackie Academic \& Professional.

Alloway, B.J., Scorrocks V.M. (1988). Copper in plant, animal and human nutrition. Hemel Hempstead, UK. Copper Development Association.

Besnard, E., Chenu, C. Robert, M. (2001). Influence of organic amendments on copper distribution among particle-size and density fractions in Champagne vineyards soils. Environmental Pollutions, 112(3), 329-337. doi:10.1016/S0269-7491(00)00151-2

Brun, L.A., Croff, J. Le., Maillet, J. (2003). Effects of elevated soil cooper on phenology, growth and reproduction of five ruderal plan species. Environmental Pollution, 122(3), 361-368. doi:10.1016/S0269-7491(02)00312-3
Chakraborty, A., Tiedemann, V., Teng, P.S. (2000). Climate change: potential impact on plant diseases. Environmental Pollution, 108(3), 317-326. doi:10.1016/S0269-7491(99)00210-9

Consalter, A., Rigato, A., Clamor, L., Giandon, P. (1992). Determination of nitrate in vegetables using an ion - selective electrode. Journal of Food Composition and Analysis, 5(3), 252-256. doi:10.1016/0889-1575(92)90044-K

Dag, A., Harlev, G., Lavee, S., Zipori, I., Kerem, Z. (2014). Optimizing olive harvest time under hot climatic conditions of Jordan Valley, Israel. European Journal of Lipid Science and Technology, 116, 169-176. doi:10.1002/ejlt.201300211

Delas, J. (1963). La toxicité du cuivre accumulé dans les sols. Agrochimica, 7, 258-288.

Acta agriculturae Slovenica, 111 - 2, september 2018 
Georgopoulos, P. G., Roy, A., Yonone-Lioy, M. J., Opiekun, R. E., Lioy, P. J. (2001). Copper: Environmental dynamics and human exposure issues. Environmental and Occupational Health Sciences Institute (EOHSI), Piscataway, Cranford, NJ 07016.

Gessa, C. E., Ciavatta, C. (2005). Gli elementi nutritivi - Rame. V P. Sequi (Ur.), Fondamenti di chimica delsuolo (str. 399-400). Bologna: Pàtron Editore.

Gómez, J.A., Guzmán, M.G., Giráldez, J.V., Fereres, E. (2009). The influence of cover crops and tillage on water and sediment yield, and on nutrient, and organic matter losses in an olive orchard on a sandy loam soil. Soil and Tillage Research, 106(1), 137144. doi:10.1016/j.still.2009.04.008

Gucci, R., Caruso, G., Bertolla, C., Urbani, S., Tatichi, A., Esposto, S., Servili, M., Sifola, M.I., Pellegrini, S., Pagliai, M., Vignozzi, N. (2012). Changes of soil properties and tree performances induced by soil management in a high-density olive orchard. European Journal of Agronomy, 41(1), 18-27. doi:10.1016/j.eja.2012.03.002

International Organization for Standardization. (1999). Soil quality - Determination of nitrate nitrogen, ammonium nitrogen and total soluble nitrogen in air-dry soils using calcium chloride solution as extractant (ISO Standard No. 14255). Pridobljeno s https://www.iso.org/standard/23081.html

International Organization for Standardization. (2003). Water quality - Application of inductively coupled plasma mass spectrometry (ICP-MS) - Part 2: Determination of 62 elements (ISO Standard No. 17294). https://www.iso.org/standard/36127.html

Kajfež-Bogataj, L. (2005). Podnebne spremembe in njihovi vplivi na kakovost življenja ljudi. Acta agriculturae Slovenica, 85(1), 41-54.

Kutilek, M., Nielsen D.R. (1994). Soil Hydrology. Germany. Catena Verlag, Cremlingen Destedt.

Moreno, B., García-Rodríguez, S., Cañizares, R., Castro, J., Benítez, E. (2009). Rainfed olive farming in South-eastern Spain: long-term effect of soil management on biological indicators of soil quality. Agriculture, Ecosystems and Environment, 131(3-4), 333-339. doi:10.1016/j.agee.2009.02.011

Ozdemir, Y. (2016). Effects of climate change on olive cultivation and table olive and olive oil quality. Horticulture, LX, 65-69.

Pintar, M., Tratnik, M., Cvejić, R., Bizjak, A., Meljo, J., Kregar, M., Zakrajšek, J., Kolman, G., Bremec, U., Drev, D., Mohorko, T., Kodre, N., Steinman, F., Kozelj, K., Prešeren, T., Kozelj, D., Urbanc, J., Mezga, K. (2010). Ocena vodnih perspektiv na območju Slovenije in možnosti rabe vode $v$ kmetijski pridelavi. Ciljni raziskovalni program: končno poročilo. Biotehniška fakulteta. Ljubljana.

Podgornik, M. \& Bandelj, D. (2015). Deficitni princip namakanja oljčnih nasadov v Slovenski Istri. Acta agriculturae Slovenica, 105(2), 337-344. doi:10.14720/aas.2015.105.2.17

Ponti, L., Gutierrez, A. P., Ruti, P. M., Dell'Aquila, A. (2014). Fine-scale ecological and economic assessment of climate change on olive in the Mediterranean Basin reveals winners and losers. Proceedings of the National Academy of Sciences, 111(15), 5598-5603. doi:10.1073/pnas.1314437111

Reports of the scientific committee for food. (1997). Food science and techniques. European Commission Pridobljeno s http://ec.europa.eu/food/fs/sc/scf/reports/scf_report s_38.pdf

Rusjan, D., Strlič, M., Pucko, D., Korošec Koruza, Z. (2007). Copper accumulation regarding the soil characteristics in Sub-Mediterranean vineyards of Slovenia. Geoderma, 141(1-2), 111-118. doi:10.1016/j.geoderma.2007.05.007

Sancin, V. (1990). Velika knjiga o oljki. Trst, Založništvo Tržaškega tiska.

Scharpf, H. C. (1991). Nutrient influences on the nitrate content of vegetables. The Fertiliser Society. Greenhill House, Thorpe Wood, Peterborough.

Seznam registriranih fitofarmacevtskih sredstev. (2018). Seznam registriranih fitofarmacevtskih sredstev. Ministrstvo za kmetijstvo, gozdarstvo in prehrano, Urad RS za varno hrano, veterinarstvo in varstvo rastlin. Pridobljeno s http://spletni2.furs.gov.si/FFS/REGSR/index.htm

Strategija za izvajanje resolucije...(2014). Strategija za izvajanje resolucije o strateških usmeritvah razvoja slovenskega kmetijstva in živilstva do leta 2020. Ministrstvo za kmetijstvo in okolje. Pridobljeno s http://www.mkgp.gov.si/fileadmin/mkgp.gov.si/pag euploads/podrocja/SKP/STRATEGIJA_12_6_2014 .pdf

Sutherst, R.W., Yonow, T., Chakraborty, S., O'Donnell, C. and White, N. (1995). A generic approach to defining impacts of climate change on pests, weeds and diseases in Australasia. V: W. J. Bouma, G. I. Pearman, M. R. Manning(Ur.), Greenhouse: coping with Climate Change (str. 281-307) Melbourne: CSIRO.

Tehnološka navodila za integrirano pridelavo sadja. (2011). Tehnološka navodila za integrirano pridelavo sadja. Ministrstvo za kmetijstvo, gozdarstvo in prehrano. Pridobljeno s 
http://www.mkgp.gov.si/fileadmin/mkgp.gov.si/pag euploads/podrocja/Kmetijstvo/Integrirana_pridelav a/TN_IPS_2012.pdf

Uredba komisije (ES) o določitvi podrobnih pravil za izvajanje Uredbe Sveta (ES) št. 834/2007 o ekološki pridelavi in označevanju ekoloških proizvodov glede ekološke pridelave, označevanja in nadzora (Uredba komisije (ES) št. 889/2008)

Uredba o mejnih vrednostih vnosa nevarnih snovi in gnojil v tla (Uradni list RS, št. 84/05, 62/08, 62/08, $113 / 09,99 / 13$ in $19 / 17$ )

Uredba o standardnih kakovosti podzemne vode (Uradni list RS, št. 100/2005).

Uredba o uporabi blata iz komunalnih čistilnih naprav $\mathrm{V}$ kmetijstvu (Uradni list RS, št. 62/08)
Valé, M., Mary, B., Justes, E. (2007). Irrigation practices may affect denitrification more than nitrogen mineralization in warm climatic conditions. Biology and Fertility of Soils, 43(6), 641-651. doi:10.1007/s00374-006-0143-0

Vitanović E. (2012) Use of Cu Fungicides in Vineyards and Olive Groves. D. Dhanasekaran, N. Thajuddin and A. Panneerselvam (Ur.) Fungicides for Plant and Animal Diseases (str. 281-298). InTech Open Science.

WHO. (1993). Guidelines for drinking water quality. 1. Recommendations. Second ed.

Geneva World Health Organization. 